\title{
Synthesis, Herbicidal Activity and Molecular Docking of some New Chloroacetamide Derivatives
}

\author{
Saad R. El-Zemity*, Kareem E. E. Esmaiel, and Mohamed E. I. Badawy
}

\begin{abstract}
Four novel chloroacetamide derivatives were synthesized 2-Chloro- $N-(2,4-$ dichlorobenzyl)- $N-(3,5-$ dimethylphenyl)acetamide (2), 2-Chloro- $\mathrm{N}-(2,4-$ dichlorobenzyl)-N-(2,5-dichlorophenyl)acetamide (4), 2Chloro-N-cinnamyl-N-(4-sulfamoylphenyl)acetamide (6) and 2-chloro- $\mathrm{N}-(2,5-$ dichlorophenyl)- $\mathrm{N}-(2-$ hydroxybenzyl)acetamide (8) and evaluated as herbicidal agents against two weed species; Anagallis arvensis as broad leaf weed and Lolium temulentum as a narrow weed in comparison with acetochlor as a standard herbicide. Mass spectra, ${ }^{1} \mathrm{H}-\mathrm{NMR}$ and ${ }^{13} \mathrm{C}-\mathrm{NMR}$ had approved the chemical structures of the synthesized compounds. Depending on the estimation of chlorophyll content, compounds 4 and 2 have been characterized as the most potent, against tested weeds and had $\mathrm{EC}_{50}$ values lower than acetochlor as standard herbicide. In addition, the molecular docking to the active sites of Very Long Chain Fatty Acid Synthase (VLCFAs) as a target enzyme shown that the derivatives gave minimal binding energy and acceptable affinity for the active site.
\end{abstract}

Keywords: Synthesis; Chloroacetamide derivatives; Herbicidal activity; Docking; VLCFAs.

\section{INTRODUCTION}

Plant protection measures can prevent yield losses due to harmful pests (Vats 2015). Weeds cause a tremendous loss in crop production worldwide (Saad et al. 2019). To overcome the weeds problems, chemical control considered a tool of modern agriculture and use of herbicides, which significantly affected on the quality and quantity of crop yields since their application (Gianessi 2013; Perotti et al. 2020). Notwithstanding, the development of herbicide resistance or toleranc in weeds, is because of in alot of cases is to use one herbicide mechanism of action, makes weeds management a big challenge, especially as no herbicide with a new site of action has registered the market for years (Heap 2014). A total of 642 unique cases of resistant weeds were reported from 1957 to 2021 along with a dramatic increase in weed resistance to two or more herbicides (www.weedscience.org). However, now days the introduction of novel herbicides with either a new mode of action or new chemical classes has

DOI: 10.21608/asejaiqjsae.2021.169608

${ }^{1}$ Pesticide Chemistry and Technology Department, Faculty of Agriculture, 21545-El-Shatby, Alexandria University, Alexandria, Egypt

* Address correspondence to Saad R. El-Zemity, Department of Pesticide

Chemistry and Technology, Faculty of Agriculture, 21545-El-Shatby,

Alexandria University, Alexandria, Egypt. Phone: 002039575269;

Fax: 002035972780; E-mail: Saad elzemity@yahoo.com

Received March 21, 2021, Accepted, May 05, 2021. been extensively investigated (Kraehmer et al. 2014). Unlikely, more than $60 \%$ of the global market of herbicides is represented by products with the mode of action, which already have serious resistance issues such as VLCFAs, 5-enolpyruvylshikimate-3-phosphate synthase, acetolactate synthase, acetyl co-enzyme A carboxylase, and auxins (Jeschke 2016). Molecular docking became necessary to evaluate the binding mechanism of novel herbicides with the active sites of the target enzymes (Fu et al. 2017; Fu et al. 2019). The widespread problems of herbicide-resistant weeds in economic field crops, is a big challenge for global food security (Powles 2014). In herbicide discovery research, the discovery of new herbicides with low-toxicity and high-activity still consider a significant challenge (Fu et al. 2017).

The chloroacetamide herbicides group is an important class of successful herbicide classes. Its main target is the inhibition elongation of Very Long Chain Fatty Acid Synthesis (VLCFAs) located in the plant plasma membrane (Götz and Böger 2004). The absence of the membrane loses the stability of plant and becomes leaky, leading to the death of the herbicidetreated plant (Götz and Böger 2004). Although chloroacetamides are an old herbicide class but still going strong in weed control in maize and rice fields (Böger 2003; Mallory-Smith and Retzinger 2003; Matthes et al. 1998; Schmalfuß et al. 1998).

As long as, the current study was aimed to synthesis four chloroacetamide derivatives by replacing the aliphatic moiety in chloroacetamide herbicides such as acetochlor, alachlor and $s$-metalachlor with aromatic part. Chloroacetamides preparation were carried out through a formation of Schiff base mechanism and followed by chloroacetylation. The spectroscopic characterizations of the synthesized compounds were examined. The herbicidal activity was evaluated against two weed species; Anagallis arvensis as broadleaf weed and Lolium temulentum as a grass weed compared with acetochlor as a standard herbicide. The results obtained were further supported by the molecular docking studies 
using enzyme VLCFAs to discover the possibilty binding action.

\section{MATERIALS AND METHODS}

\section{Chemicals and instruments}

All chemicals were purchased from Sigma Aldrich Co. (USA). Standard herbicide, acetochlor was obtained from Egyptchem International for Agrochemicals, Egypt, under trade name of Host Core $90 \%$ EC with local registration number 2570, with 1.1 L/ $200 \mathrm{~L}$ water/feddan. Melting points were determined in open glass capillaries using a Griffin melting point apparatus. All spectra of the synthetic compounds were identified and confirmed using nuclear magnetic resonance $\left({ }^{1} \mathrm{H}-\mathrm{NMR}\right.$ and ${ }^{13} \mathrm{C}-\mathrm{NMR}$ ) (Bruker HighPerformance Digital NMR Spectrometer Avance III 400 $\mathrm{MHz}$, Faculty of Pharmacy, Mansoura University, Egypt) using deuterated dimethyl sulfoxide as a solvent. The data were reported as chemical shifts $(\delta, \mathrm{ppm})$ relative to tetramethylsilane (TMS) as internal standard. Signals were indicated by the following abbreviations: $s$ singlet, $d=$ doublet, $t=$ triplet, $q=$ quartet and $m=$ multiplet. Electron impact mass spectra (EIMS) were run on a mass spectrometer at Al-Azhar University (The Regional Center of Mycology and Biotechnology, Cairo). Relative intensity (\%) corresponding to the most characteristic fragments was recorded. During the synthesis, reaction progress was monitored by thin-layer chromatography (TLC) on a silica gel sheet (60 GF245. Merck, USA). UV-lamp visualized the spots at $\lambda 254$ $\mathrm{nm}$ for a few seconds.

\section{Synthesis of chloroacetamide derivatives}

The same strategy for synthetic route of typical standard herbicides (acetochlor, metochlor and $s$ metochlor) were used for the synthesis of chloroacetamide derivatives which based on the formation of Schiff base followed by chloroacetylation of imines (Abdel-Latif et al. 2020).

General procedure for the preparation of chloroacetamide derivatives

The derivatives were prepared according to two steps (Figure 1). Firstly, Schiff bases (1, 3, 5, and 7) were synthesized as the following method: To $0.01 \mathrm{~mol}$ of series of amines dissolved in $20 \mathrm{~mL}$ methyl alcohol in a $50 \mathrm{~mL}$ dry round bottom flask, $0.01 \mathrm{~mol}$ of corresponding aldehydes (salicylaldehyde, 2,4dichlorobenzaldehyde and cinnamaldehyde) was added dropwise. After the complete addition of aldehyde, 1 $\mathrm{mL}$ of glacial acetic acid was added to the reaction mixture and stirred using a magnetic stirrer at room temperature $\left(25^{\circ} \mathrm{C}\right)$ for $10-20 \mathrm{~min}$. The reaction progress was monitored by TLC. When the reaction was completed, the solvent was removed using a vacuum evaporator. The crude products were washed by ether, affording the Schiff base derivatives of series of amines.
Secondly, the imine derivatives $(\mathbf{1}, \mathbf{3}, \mathbf{5}$, and 7) were dissolved in dichloromethane and cooled at $0-5^{\circ} \mathrm{C}$ using the ice-water bath. A separately prepared solution of chloroacetyl chloride in dichloromethane was added dropwise to the above mixture. The mixtures were stirred for $3 \mathrm{~h}$ in a water-ice mixture and a further three $\mathrm{h}$ at ambient temperature. The solvents were evaporated on a rotary evaporator to obtain the chloroacetamide derivatives $(\mathbf{2}, \mathbf{4}, \mathbf{6}$, and 8). Products were washed with water and crystallized in methanol (Murtaza et al. 2019).

(E)-1-(2,4-dichlorophenyl)-N-(3,5dimethylphenyl)methanimine (1)

A pale-yellow powder; yield $75 \%$; mp, $136-138^{\circ} \mathrm{C}$. ${ }^{1} \mathrm{H}-\mathrm{NMR}\left(400 \mathrm{MHz}, \mathrm{DMSO}-\mathrm{d}_{6}, \mathrm{ppm}\right) \delta: 2.25$ ( $s, 6 \mathrm{H}$, $\left.\mathrm{CH}_{3},-\underline{\mathrm{CH}}_{3}\right) ; 6.68$ ( $s, 1 \mathrm{H}, \mathrm{C} 4$ of phenyl); $7.19(\mathrm{~s}, 2 \mathrm{H}, \mathrm{C} 2$, C6 of phenyl); 7.44-7.47 (d, 1H, C5 of benzyl); 7.747.77 ( $d, 1 \mathrm{H}, \mathrm{C} 6$ of benzyl); $7.98(s, 1 \mathrm{H}, \mathrm{C} 3$ of benzyl); $8.64(s, 1 \mathrm{H}, \underline{\mathrm{HC}}=\mathrm{N})$. EIMS, $\mathrm{m} \backslash \mathrm{z}$ (relative abundance, \%): 35 (72.39); 150.47 (45.65); 182.36 (54.56); 214.36 (100.00); 230.60 (42.35); 265.44 (96.36); $280.41\left(\mathrm{M}^{+2 .}\right)$ (70.28) HRMS (ESI) $\mathrm{m} \backslash \mathrm{z}$ : calculated for $\left[\mathrm{C}_{15} \mathrm{H}_{11} \mathrm{Cl}_{2} \mathrm{~N}\right]^{+}$ 278.18 found 280.41 .

\section{2-Chloro-N-(2,4-dichlorobenzyl)-N-} (3,5dimethylphenyl)acetamide (2)

A white crystal; yield $77 \%$; mp, $141-142^{\circ} \mathrm{C} .{ }^{1} \mathrm{H}-$ NMR (400 MHz, DMSO-d 6 , ppm) $\delta: 2.25\left(s, 6 \mathrm{H},-\mathrm{CH}_{3}\right.$, $\left.-\underline{\mathrm{CH}}_{3}\right) ; 4.23\left(s, 4 \mathrm{H}, \mathrm{CH}_{2}\right.$ of chloroacetyl and $\left.\mathrm{NC}_{2}\right)$; $6.74(s, 1 \mathrm{H}, \mathrm{C} 4$ of phenyl); $7.21(s, 2 \mathrm{H}, \mathrm{C} 2, \mathrm{C} 6$ of phenyl); 7.63-7.66 ( $d, 1 \mathrm{H}, \mathrm{C} 5$ of benzyl); 7.87-7.90 $(d$, $1 \mathrm{H}$, C6 of benzyl); $10.16\left(s, 1 \mathrm{H}, \mathrm{C} 3\right.$ of benzyl). ${ }^{13} \mathrm{C}-$ NMR (100 MHz, DMSO-d 6, ppm) $\delta: 21.55\left(2 \mathrm{C},-\underline{C H}_{3},-\right.$ $\left.\underline{\mathrm{CH}}_{3}\right) ; 44.09\left(2 \mathrm{C}, \mathrm{NCH}_{2}, \underline{\mathrm{CH}}_{2}\right.$ of chloroacetyl); 117.57 (2C, C2, C6 of phenyl); 125.86 (4C, C3, C5, C6 of benzyl and $\mathrm{C} 4$ of phenyl); 138.33 (4C, C2, C4 of benzyl and $\mathrm{C} 3, \mathrm{C} 5$ of phenyl); 138.80 (2C, C1 of benzyl and $\mathrm{C} 1$ of phenyl) and $164.94(\underline{\mathrm{C}}=\mathrm{O})$. HRMS (ESI) $\mathrm{m} \backslash \mathrm{z}$ : calculated for monoisotopic mass $\left[\mathrm{C}_{20} \mathrm{H}_{18} \mathrm{Cl}_{2} \mathrm{NO}_{2}\right]^{+}$ 356.67 found 356.06 .

(E)-1-(2,4-dichlorophenyl)-N-(2,5dichlorophenyl)methanimine (3)

A white to pale-yellow crystal; yield 95\%; mp, 103$104^{\circ} \mathrm{C} .{ }^{1} \mathrm{H}-\mathrm{NMR}\left(400 \mathrm{MHz}, \mathrm{DMSO}-\mathrm{d}_{6}, \mathrm{ppm}\right) \delta: 7.12-$ $7.14(d, 2 \mathrm{H}, \mathrm{C} 5, \mathrm{C} 6$ of benzyl); 7.26-7.28 (d, 2H, C3, $\mathrm{C} 4$ of phenyl); $7.94(s, 2 \mathrm{H}, \mathrm{C} 6$ of phenyl and $\mathrm{C} 3$ of benzyl).8.24 $(s, 1 \mathrm{H}, \underline{\mathrm{HC}}=\mathrm{N})$. EIMS, $\mathrm{m} \backslash \mathrm{z}$ (relative abundance, \%): 141 (78.35); 163.23 (56.96); 202.60 (100.00); $265.55 \quad$ (86.65); $287.45 \quad$ (67.70); 308.43 (68.00); $323.07 \quad\left(\mathrm{M}^{+4}\right)$ (48.21) HRMS (ESI) $\mathrm{m} \backslash \mathrm{z}$ : calculated for $\left[\mathrm{C}_{13} \mathrm{H}_{7} \mathrm{Cl}_{4} \mathrm{~N}\right]^{+} 319.01$ found 323.07. 

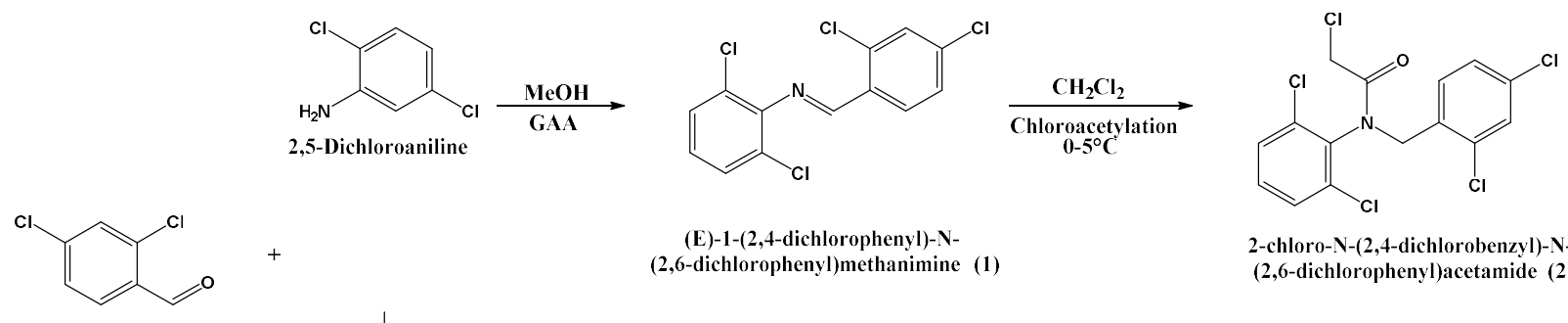

(E)-1-(2,4-dichlorophenyl)-N(2,6-dichlorophenyl)methanimine (1)

2-chloro-N-(2,4-dichlorobenzyl)-N(2,6-dichlorophenyl)acetamide (2)

2,4-

Dichlorobenzaldehyde
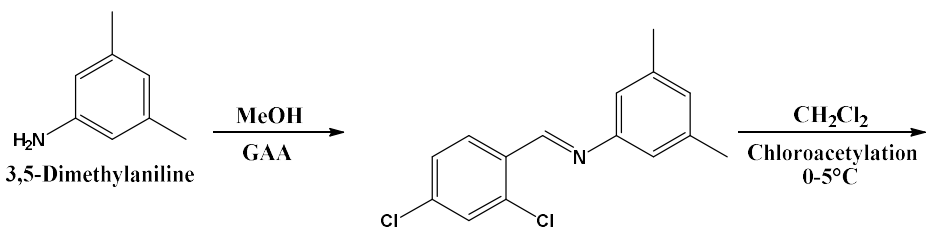

(E)-1-(2,4-dichlorophenyl)-N(3,5-dimethylphenyl)methanimine (3)

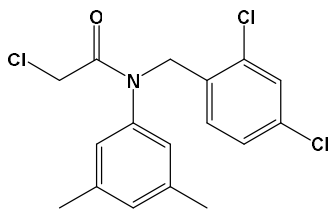

2-chloro-N-(2,4-dichlorobenzyl)-N(3,5-dimethylphenyl)acetamide (4)

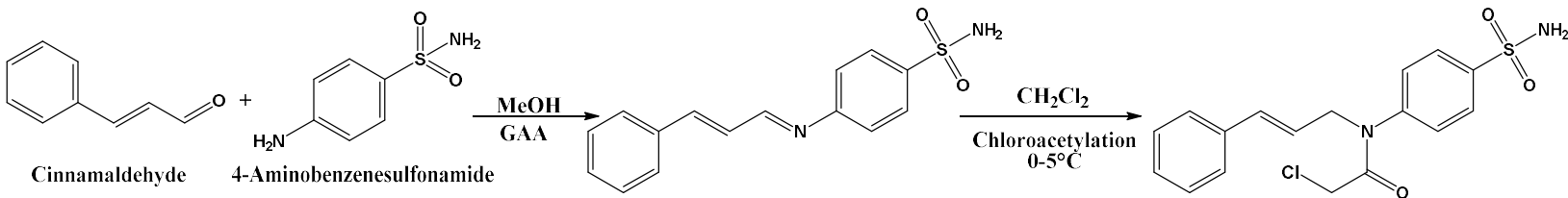

4-(((1E,2E)-3-phenylallylidene) amino)benzenesulfonamide (5)

2-chloro-N-cinnamyl-N(4-sulfamoylphenyl)acetamide (6)

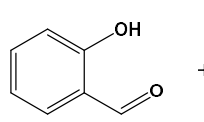

Salicylaldehyde

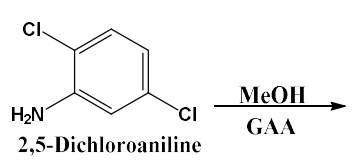<smiles>Oc1ccccc1/C=N/c1cc(Cl)ccc1Cl</smiles>

$\frac{\mathrm{CH}_{2} \mathrm{Cl}_{2}}{\substack{\text { Chloroacetylation } \\ 0-5^{\circ} \mathrm{C}}}$

(E)-2-(((2,5-dichlorophenyl) imino)methyl)phenol (7)

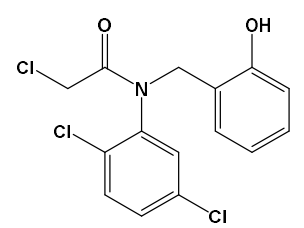

2-chloro-N-(2,5-dichlorophenyl)-N(2-hydroxybenzyl)acetamide (8)

Figure 1. Synthetic route of four chloroacetamide derivatives

\section{2-Chloro-N-(2,4-dichlorobenzyl)-N-(2,5- dichlorophenyl)acetamide (4)}

A beige crystal; yield $72 \%$; mp, $118-119{ }^{\circ} \mathrm{C} .{ }^{1} \mathrm{H}-$ NMR (400 MHz, DMSO-d 6 , ppm) $\delta: 4.42\left(s, 4 \mathrm{H}, \mathrm{CH}_{2}\right.$ of chloroacetyl and $\left.\mathrm{NC}_{2}\right)$; 7.31-7.33 (d, 2H, C5, C6 of benzyl); 7.57-7.59 ( $d, 2 \mathrm{H}, \mathrm{C} 3, \mathrm{C} 4$ of phenyl); $7.90(s$, $2 \mathrm{H}$, C6 of phenyl and $\mathrm{C} 3$ of benzyl). ${ }^{13} \mathrm{C}-\mathrm{NMR}(100$ $\left.\mathrm{MHz}, \mathrm{DMSO}-\mathrm{d}_{6}, \mathrm{ppm}\right) \delta: 41.12$ ( $\underline{\mathrm{CH}}_{2}$ of chloroacetyl); $43.61\left(\mathrm{NCH}_{2}\right) ; 120.84$ (C6 of chlorophenyl); 124.43 (C4 of chlorophenyl); 127.31 (C5 of chlorobenzyl); 127.82 (C3 of chlorophenyl); 128.82 (C6 of chlorobenzyl); 129.02 (C3 of chlorobenzyl); 129.29 (C5 of chlorophenyl); 130.00-130.79 (2C, C2, C4 of chlorobenzyl); 131.55 (C2 of chlorophenyl); 136.08 (C1 of chlorobenzyl); 141.15 (C1 of chlorophenyl) and $167.00 \quad(\underline{C}=\mathrm{O})$. HRMS (ESI) $\mathrm{m} \backslash \mathrm{z}$ : calculated for monoisotopic mass $\left[\mathrm{C}_{15} \mathrm{H}_{10} \mathrm{Cl}_{5} \mathrm{NO}\right]^{+} 397.50$ found 397.98 .
4-((1E,2E)-3phenylallylidene)amino)benzenesulfonamide (5)

A darkish brown powder; yield $85 \%$; mp, 193$194{ }^{\circ} \mathrm{C}$; ${ }^{1} \mathrm{H}-\mathrm{NMR}\left(400 \mathrm{MHz}, \mathrm{DMSO}-\mathrm{d}_{6}, \mathrm{ppm}\right) \delta: 7.17-$ $7.23(m, 1 \mathrm{H}, \mathrm{CH}=\mathrm{C} \underline{\mathrm{H}} \mathrm{CHN}), 7.32\left(s, 2 \mathrm{H},-\mathrm{NH}_{2}\right), 7.34-$ 7.36 ( $d$, 2H C2, C6 of benzene-sulfonamide), 7.42-7.46 $(m, 3 \mathrm{H}, \mathrm{C} 3, \mathrm{C} 4$ and $\mathrm{C} 5$ of phenyl), 7.46-7.48 $(d, 1 \mathrm{H}$, $\mathrm{C} \underline{\mathrm{H}}=\mathrm{CHCHN}), 7.71-7.72(d, 2 \mathrm{H}, \mathrm{C} 2, \mathrm{C} 6$ of phenyl $)$, 7.83-7.85 (d, 2H, C3, C5 of benzene-sulfonamide) 8.41$8.43(d, 1 \mathrm{H}, \quad \mathrm{CH}=\mathrm{CHC} \underline{\mathrm{HN}})$. HRMS (ESI) $\mathrm{m} \backslash \mathrm{z}$ : calculated for monoisotopic mass $\left[\mathrm{C}_{15} \mathrm{H}_{14} \mathrm{~N}_{2} \mathrm{O}_{2} \mathrm{~S}\right]^{+}$ 286.35 found 286.20 .

\section{2-Chloro-N-cinnamyl-N-(4- sulfamoylphenyl)acetamide (6)}

A yellow powder; yield $75 \%$; mp, $233-234{ }^{\circ} \mathrm{C} ;{ }^{1} \mathrm{H}-$ NMR (400 MHz, DMSO-d 6 , ppm) $\delta: 4.29\left(s, 2 \mathrm{H}, \mathrm{C}_{2}\right.$ of chloroacetyl); 4.85-4.87 (d, 2H, $\left.\mathrm{NC}_{2}\right) ; 7.17-7.30$ $\left(m, \quad 1 \mathrm{H}, \quad \mathrm{CH}=\mathrm{CHCH}_{2} \mathrm{~N}\right) ; \quad 7.36-7.49 \quad(d, \quad 5 \mathrm{H}$, 
$\mathrm{C} \underline{\mathrm{H}}=\mathrm{CHCH}_{2} \mathrm{~N}, \mathrm{C} 2, \mathrm{C} 6$ of phenyl and $\mathrm{C} 2, \mathrm{C} 6$ of benzene-sulfonamide); $7.55\left(s, 2 \mathrm{H},-\mathrm{NH}_{2}\right) ; 7.72-7.80$ ( $m, 3 \mathrm{H}, \mathrm{C} 3, \mathrm{C} 4, \mathrm{C} 5$ of phenyl); 7.97-7.99 $(d, 1 \mathrm{H}, \mathrm{C} 3$ of benzene-sulfonamide); $9.68-9.70(d, 1 \mathrm{H}, \mathrm{C} 5$ of benzenesulfonamide); ${ }^{13} \mathrm{C}-\mathrm{NMR}\left(100 \mathrm{MHz}, \mathrm{DMSO}-\mathrm{d}_{6}, \mathrm{ppm}\right) \delta$ : $55.77\left(\mathrm{CH}_{2}\right.$ of chloroacetyl); $57.01\left(\mathrm{NCH}_{2}\right) ; 121.66(2 \mathrm{C}$, $\mathrm{C} 2$, $\mathrm{C} 6$ of benzene-sulfonamide); 126.25-126.81 $\left(\mathrm{CH}=\mathrm{CHCH}_{2} \mathrm{~N}\right) ; 127.76$ (C4 of phenyl); 128.03-128.99 (2C, C2, C6 of phenyl); 129.24-129.57 (2C, C3, C5 of phenyl); 129.65-130.32 (2C, C3, C5 of benzenesulfonamide); $131.73\left(\mathrm{CH}=\mathrm{CHCH}_{2} \mathrm{~N}\right) ; 134.54(\mathrm{C} 1$ of phenyl); 134.66 (C4 of benzene-sulfonamide); 153.76 (C1 of benzene-sulfonamide) and $166.59(\underline{\mathrm{C}}=\mathrm{O})$. HRMS (ESI) $\mathrm{m} \backslash \mathrm{z}$ : calculated for monoisotopic mass [ $\left.\mathrm{C}_{17} \mathrm{H}_{17} \mathrm{ClN}_{2} \mathrm{O}_{3} \mathrm{~S}\right]^{+} 364.84$ found 364.71 .

\section{(E)-2-(((2,5-dichlorophenyl)imino)methyl)phenol (7)}

A white to pale yellow crystal; yield $90 \%$; mp, 106$107^{\circ} \mathrm{C}$. ${ }^{1} \mathrm{H}-\mathrm{NMR}\left(400 \mathrm{MHz}, \mathrm{DMSO}-\mathrm{d}_{6}, \mathrm{ppm}\right) \delta: 7.02-$ $7.04(d, 1 \mathrm{H}, \mathrm{C} 6$ of hydroxybenzyl), 7.11-7.13 ( $\mathrm{m}, 2 \mathrm{H}$, $\mathrm{C} 4, \mathrm{C} 5$ of hydroxybenzyl), 7.31-7.33 (d, 2H, C3, C4 of phenyl), 7.58( $s, 1 \mathrm{H}, \mathrm{C} 6$ of phenyl), 7-79-7.81 (C3 of hydroxybenzyl), $9.12(s, 1 \mathrm{H}, \underline{\mathrm{HC}}=\mathrm{N}), 12.78(s, 1 \mathrm{H}$, $\mathrm{OH})$. EIMS, $\mathrm{m} \backslash \mathrm{z}$ (relative abundance, \%): 99.36 (59.19); 181.83 (89.89); 156.60 (42.55); 188.25 (100.00); 220.74 (73.95); 231.27 (45.76); $268.18\left(\mathrm{M}^{+2}\right)$ (34.38) HRMS (ESI) $\mathrm{m} \backslash \mathrm{z}$ : calculated for $\left[\mathrm{C}_{13} \mathrm{H}_{9} \mathrm{Cl}_{2} \mathrm{NO}^{+} 266.12\right.$ found 268.18 .

\section{2-Chloro-N-(2,5-dichlorophenyl)-N-(2- hydroxybenzyl)acetamide (8)}

An off-white crystal; yield $40 \%$; mp, $111-112^{\circ} \mathrm{C}$. ${ }^{1} \mathrm{H}-\mathrm{NMR}$ (400 MHz, DMSO-d 6 , ppm) $\delta: 4.42(s, 4 \mathrm{H}$, $\mathrm{CH}_{2}$ of chloroacetyl and $\left.\mathrm{NCH}_{2}\right) ; 7.31-7.33(\mathrm{~m}, 2 \mathrm{H}, \mathrm{C} 4$, C5 of hydroxybenzyl); 7.57-7.59 $(d, 2 \mathrm{H}, \mathrm{C} 3, \mathrm{C} 6$ of hydroxybenzyl); 7.70-7.72 ( $d, 2 \mathrm{H}, \mathrm{C} 3, \mathrm{C} 4$ of phenyl); $7.90\left(s, 1 \mathrm{H}, \mathrm{C} 6\right.$ of phenyl); $10.01(s, \mathrm{OH}) .{ }^{13} \mathrm{C}-\mathrm{NMR}$ (100 MHz, DMSO-d 6 , ppm) $\delta: 41.99\left(\mathrm{NCH}_{2}\right), 55.88$ $\left(\mathrm{CH}_{2}\right.$ of chloroacetyl); 115.20 (C3 of hydroxybenzyl); 120.15 (C5 of hydroxybenzyl); 122.81 (C6 of phenyl); 123.39 (C4 of phenyl); 124.55-125.03 (2C, C4, C6 of hydroxybenzyl); 129.26 (C1 of hydroxybenzyl); 132.90 (C5 of phenyl); 135.59 (C2 of phenyl); 136.81 (C1 of phenyl); 159.97 (C2 of hydroxybenzyl) and 165.77 $(\underline{\mathrm{C}}=\mathrm{O})$. HRMS (ESI) $\mathrm{m} \backslash \mathrm{z}$ : calculated for monoisotopic mass $\left[\mathrm{C}_{15} \mathrm{H}_{12} \mathrm{Cl}_{3} \mathrm{NO}_{2}\right]^{+} 344.62$ found 344.20.

\section{Herbicidal activity of new chloroacetamide derivatives}

The herbicidal activity of new chloroacetamide derivatives was assessed as foliar applications against two weed species; scarlet pimpernel (A. arvensis) as a broadleaf weed and darnel ryegrass (L. temulentum) as a grass weed. Plants were grown in seedling growing peat moss tray in $\left(19 \times 11 \mathrm{~cm}^{2}\right)$ pots for 7-21 days in a greenhouse with a $15 \mathrm{~h}$ photoperiod maintained 23$29^{\circ} \mathrm{C}$ during the day and $22-28^{\circ} \mathrm{C}$ during the night.
Plants were grown to 3 to 5 leaf stage before applications (Epp et al. 2016). Stock solutions were weighting an amount (determined by the highest rate to be tested that calculated as acetochlor rate $1.1 \mathrm{~L} / 200 \mathrm{~L} /$ feddan) of each tested molecule in a $25 \mathrm{~mL}$ glass vial and dissolving the test molecule in $4 \mathrm{~mL}$ of a 97:3 v/v mixture of acetone and dimethyl sulfoxide (DMSO), it after referred to as the Universal Solution (US). The mixture was heated and/or sonicated, if the tested molecule did not dissolve well. Stock solutions were diluted with $20 \mathrm{~mL}$ of an aqueous solution containing $\mathrm{H}_{2} \mathrm{O}$, US, isopropanol, Tensiofix D33, and Tween (80) as a surfactant at ratio of 45:43:11:2.0:0.03 $(\mathrm{v} / \mathrm{v})$ to form the spray mixtures associated with the highest application rates. Supplymental spray mixtures for the lower application rates were get by serial dilution of $12 \mathrm{~mL}$ of the high-rate solution with a solution containing $2 \mathrm{~mL}$ of US and $10 \mathrm{~mL}$ of an aqueous solution containing $\mathrm{H}_{2} \mathrm{O}$, US, isopropanol, Tensiofix D33, and Tween (80) at ratio of 45:43:11:2.0:0.03 (v/v ratio). The resulting spray solutions were 5000,2500 and $1250 \mathrm{mg} / \mathrm{L}$ representing $1,1 / 2$ and $1 / 4 \mathrm{X}$, repectively. Molecule appliction were based on a $10 \mathrm{~mL}$ application volume at a rate of 1.1 L/Fedden. Formulated molecules were applied to the weed with an atomizer nozzle adjusted to deliver 1.1 $\mathrm{L} /$ Fedden over an application area of $0.5 \mathrm{~cm}^{2}$. Control were sprayed by only solvent blank. The treated and control weeds were kept in a greenhouse and watered by sub-irrigation to prevent wash-off of the tested compounds. After 21 days, chlorophyll contents of tested and control plants were determined. The determination of chlorophyll content in leaves by the chlorophyll meter (SPAD 502) is more suitable than the extraction method where the total chlorophyll $(\mathrm{mg} / \mathrm{mg}$ plant tissue) is assesed on the same leaf over time with three replicates (Yamamoto et al. 2002). Data were subjected for probit analysis to calculate the $\mathrm{EC}_{50}$ using the SPSS 15.0 statistics package (SPSS Inc., 2007).

\section{Molecular docking}

The crystal structure of VLCFAs was downloaded from the Protein Data Bank (PDB ID 2uxw) at $1.45 \AA$ (Moche et al. 2001). Before docking, the protein structure was prepared using a molecular operating environment program (MOE 2015.10; Chemical Computing Group Montreal Canada) to remove water and some other co-crystallized small molecules. After the protein was prepared, the active pocket of the protein was defined based on the volume occupied by the known ligand pose already in an active site ( $\mathrm{Fu}$ et al. 2017). The molecules were converted to the 3Dstructured, and the Merck Molecular Force Field (MMFF94) power was minimized with a 200-iteration limit and the power threshold value of $15 \mathrm{kcal} / \mathrm{mol}$ (Halgren 1999). The binding free energy was calculated 
from the contributions of hydrophobic, ionic, hydrogenated, and van der Waals interactions between the target enzyme and ligands.

\section{RESULTS AND DISCUSSION}

\section{Chemistry}

The formation of Schiff bases from aldehydes considers a reversible reaction and generally takes place under acid catalysis or upon heating. The mechanism of Schiff base formation is another variation on the theme of nucleophilic addition to the $-\mathrm{C}=\mathrm{O}$. In this case, the amine cosiders a nucleophile. Fristally, the aldehyde reacts with the amine to give carbinolamine which considers an unstable addition molecule. The carbinolamine loses $\mathrm{H}_{2} \mathrm{O}$ by acid-catalyzed pathway. Because of carbinolamine is an alcohol, it undergoes acid-catalyzed dehydration. Typically, the dehydration of the carbinolamine is the rate-determining step of imine formation, and that is why the reaction is catalyzed by acids. Yet, the acid concentration cannot be too high because amines are basic compounds. If the amine is protonated and becomes non-nucleophilic, equilibrium is pulled to the left, and carbinolamine formation cannot occur. Therefore, many Schiff bases have been synthesized at mildly acidic pH. (Xavier and Srividhya 2014) The imine formation is proceeds in two types of reactions, addition followed by elimination (Xavier and Srividhya 2014).

The imines appear to be an vital intermediate in a number of organic compounds. Acylation of imines by acid anhydrides, acid chlorides and acyl cyanides are initiated by attack at the nitrogen atom and leads to net addition of the acylating agent to the carbon-nitrogen double bond. Those reactions of this type have been put to good use in synthesis (Vekariya et al.). The target compounds were synthesized via acylation of imine derivatives. The effects of substituent pattern on the yields were studied. It was found that different aromatic substituents displayed diverse yields, the order was as following: $\quad-N-(2,4-$ dichlorobenzyl $) \quad>-N-(2-$ hydroxybenzyl). The presence of methyl group in the phenyl ring gave high yield but slowly reaction, on the other hand, the presence of chlorine group on benzyl ring gave little yield with rapid reaction.

${ }^{1} \mathrm{H}-\mathrm{NMR}$ and ${ }^{13} \mathrm{C}$-NMR spectra had approved the chemical structures of the compounds. However, all ${ }^{1} \mathrm{H}$ NMR spectra of imine derivatives (1 and $\mathbf{3}$ ) showed a singlet signal corresponding to the imine hydrogen $\underline{\mathrm{HN}}=\mathrm{C}$ at a chemical shift between 8.24 and $8.64 \mathrm{ppm}$, respectively. But the imine derivative (5) showed a doublet signal corresponding to the same hydrogen atom at a chemical shift 8.41-8.43 ppm However, the spectrum of compound 7 showed a singlet signal corresponding to the imine hydrogen at a chemical shift between $9.12 \mathrm{ppm}$. For the confirmation of chemical structures of the target compounds $(2,4,6$ and 8$)$ there are more than one position confirmed by ${ }^{1} \mathrm{H}-\mathrm{NMR}$ and ${ }^{13} \mathrm{C}-\mathrm{NMR}$ spectra. Firstly, the hydrogen atoms of $-\mathrm{NCH}_{2}$ and $-\underline{\mathrm{CH}}_{2}$ of chloroacetyl which shown at chemical shifts of 4 to $5 \mathrm{ppm}$, secondly the carbons of $-\mathrm{NCH}_{2}$ and $-\mathrm{CH}_{2}$ of chloroacetyl which shown around 41-43 ppm and 48- $58 \mathrm{ppm}$, respectively. In addition the carbon of carbonyl group $\underline{\mathrm{C}}=\mathrm{O}$ which present usually at 164 to $167 \mathrm{ppm}$. So all spectra approved the chemical structures of the synthesized compounds.

The physiochemical properties of synthesized compounds (1-8) are shown in Table 1. The properties include a hydrophobicity factor (ALogP, octanol/water partition coefficient), hydrogen bond acceptor (HBA), hydrogen bond donor (HBD), and the log of solubility in water $(\log S)$. Also the melting points and the yield of the products are included. The ALogP was ranged from 2.45 to 6.08 . It can be noted that the conversion of the imine form for all derivatives to chloroacetamide form led to slightly decrese of the ALogP value.

Table 1. The physiochemical properties of synthesized compounds (1-8)

\begin{tabular}{cccccccc}
\hline Code & $\mathbf{m p}\left({ }^{\circ} \mathbf{C}\right)$ & Yield $(\%)$ & MW & ALogP & HBA & HBD & Log S \\
\hline $\mathbf{1}$ & $103-104$ & 95 & 319 & 6.08 & 1 & 0 & -6.35 \\
$\mathbf{2}$ & $118-119$ & 72 & 398 & 5.93 & 2 & 0 & -6.62 \\
$\mathbf{3}$ & $135-138$ & 75 & 278 & 5.73 & 1 & 0 & -5.70 \\
$\mathbf{4}$ & $141-142$ & 77 & 357 & 5.57 & 2 & 0 & -5.96 \\
$\mathbf{5}$ & $193-194$ & 85 & 286 & 2.49 & 4 & 2 & -3.81 \\
$\mathbf{6}$ & $233-234$ & 75 & 365 & 2.45 & 5 & 2 & -4.38 \\
$\mathbf{7}$ & $106-107$ & 90 & 266 & 4.51 & 2 & 1 & -4.49 \\
$\mathbf{8}$ & $111-112$ & 40 & 345 & 4.36 & 3 & & -4.92 \\
\hline
\end{tabular}

ALogP: Hydrophobicity factor (octanol/water partition coefficient). HBA: Hydrogen bond acceptor, HBD: Hydrogen bond donor, Log S: $\log$ of solubility in water (Log S scale: insoluble $<-10$, poorly -10 to -6 , moderately -6 to -4 , soluble -4 to -2 , very -2 to 0 and highly soluble $>0$ ) 


\section{Effect of the tested chloroacetamide compounds on chlorophyll content}

The herbicidal activity of the synthesized compounds against two weeds, $A$. arvensis as a broadleaf weed and $L$. temulentum as a grass weed compared with acetochlor as a standard herbicide, are shown in Figure 2. The data are presented as the $\mathrm{EC}_{50}$ values in $\mathrm{mg} / \mathrm{L}$. The results revealed that most of the tested compounds exhibited remarkable reduction for the content of chlorophyll of the two weeds. The derivative 2 was determined to be the most potent against $L$. temulentum $\left(\mathrm{EC}_{50}=2948 \mathrm{mg} / \mathrm{L}\right)$, then compound $1\left(\mathrm{EC}_{50}=3321 \mathrm{mg} / \mathrm{L}\right)$. However, the $\mathrm{EC}_{50}$ values of compounds 3 and $\mathbf{4}$ were higher than acetochlor. But all compounds having $\mathrm{EC}_{50}$ less than acetochlor against $A$. arvensis. Compound $\mathbf{4}$ was the most potent against $A$. arvensis $\left(\mathrm{EC}_{50}=3152 \mathrm{mg} / \mathrm{L}\right)$, then compounds $\mathbf{2 ,} \mathbf{1}$ and $\mathbf{3}$ $\left(\mathrm{EC}_{50}=3247,3654\right.$ and $3684 \mathrm{mg} / \mathrm{L}$ respectively $)$.

The results indicate that the presence of one or two methyl groups on the benzyl ring percent of chlorophyll reduction. But the presence of more than one hydroxyl group on the phenyl ring decreased the chlorophyll reduction in $L$. temulentum. According to the post-emergence herbicidal assay, the synthesized compounds structure-activity relationships (SARs) can be revealed. The categories of substituent groups on hydroxybenzyl and 2,4-dichlorophenyl rings have a significant impact on the herbicidal activities. However, when it was based on the chloroacetamide moiety.

\section{Molecular docking}

The docking results of the synthesized molecules and standard herbicide on the main target enzyme (VLCFAs) was performed using MOE software. The data analysis have been based on the docking score $(\Delta G, \mathrm{kcal} / \mathrm{mol})$, hydrogen bonds and van der Waals connections nearby. The results presented in Table $\mathbf{2}$ show that the synthesized derivatives have a well binding convergence with the active sites of the target protein with docking energy ranging from -5.32 to $-6.92 \mathrm{kcal} / \mathrm{mol}$ compared to -6.26 $\mathrm{kcal} / \mathrm{mol}$ for acetochlor. Two compounds $\mathbf{4}$ and $\mathbf{3}$ scored less than the standard herbicide, correspond to the enzyme binding cavity. All compounds showed HBA and hydrophobic interaction together, except compound 2 that showed only hydrophobic interaction. The distance between the binding atom in all compounds and hydrogen from the amino acid residues was measured and was found in the range of 3.20- $3.55 \AA$. However, with hydrophobic interactions it was in the range 3.85-4.46 $\AA$ and was comparable with that found in the crystal structure of the enzyme complexed with the standard herbicide (3.36 $\AA$ ). It can be noted that the amino acids Ser 251 and Thr 217 binded with the most synthesized chloroacetamide derivatives. Figures 3 shows the optimal $2 \mathrm{D}$ and $3 \mathrm{D}$ binding mode interactions diagram of the synthesized chloroacetamide derivative compared with the standard herbicide acetochlor. The root mean square deviation (RMSD) of the synthesized compounds were found in the range $0.45-1.94 \AA$.

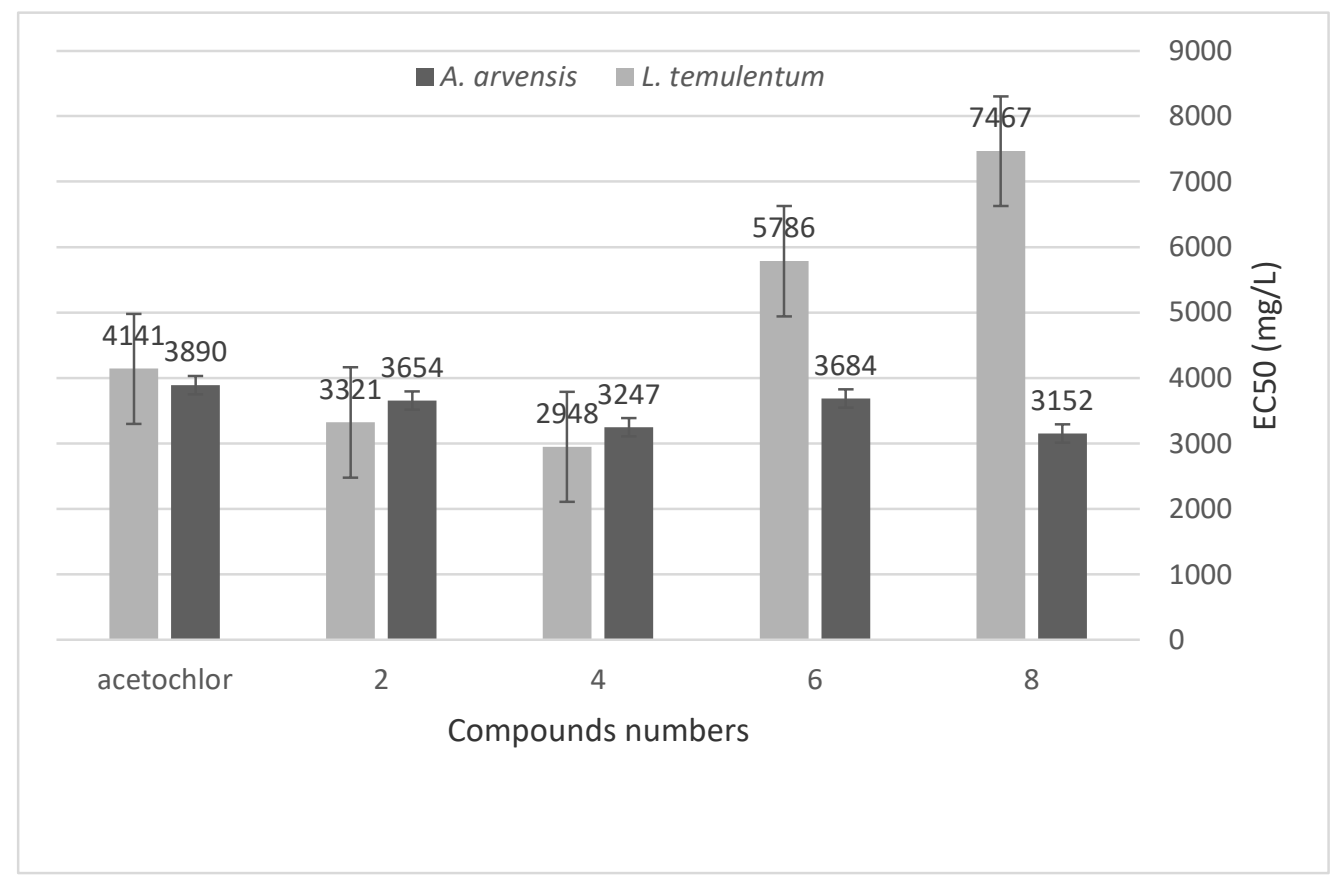

Figure 2. Herbicidal activity of synthesized chloroacetamide compounds against weeds of $A$. arvensis and $L$. temulentum 
Table 2. Molecular docking, binding scores and binding interactions of synthesized chloroacetamide derivatives within the active sites of VLCFAs (PDB ID: 2UXW) compared with acetochlor

\begin{tabular}{|c|c|c|c|c|c|c|c|c|c|}
\hline \multirow[b]{2}{*}{ Comp. } & \multirow{2}{*}{$\begin{array}{c}\text { Docking } \\
\text { score (S) } \\
\Delta \mathbf{G} \\
\text { (kcal/mol) }\end{array}$} & \multirow[b]{2}{*}{ van der Waals } & \multicolumn{3}{|c|}{ H-Bond } & \multicolumn{3}{|c|}{$\begin{array}{c}\text { Hydrophobic Interactions ( } \pi \text { - } \\
\text { interactions) } \\
\end{array}$} & \multirow[t]{2}{*}{ RMSD ${ }^{*}$} \\
\hline & & & $\begin{array}{l}\text { (Amino } \\
\text { acid- } \\
\text { ligand } \\
\text { atom) }\end{array}$ & Interaction & $\begin{array}{c}\text { Distance } \\
(\AA ̊)\end{array}$ & $\begin{array}{c}\text { (Amino } \\
\text { acid- } \\
\text { ligand } \\
\text { atom) }\end{array}$ & Interaction & $\begin{array}{c}\text { Distance } \\
(\AA)\end{array}$ & \\
\hline 2 & -6.67 & $\begin{array}{c}\text { Glu 462, Gly } \\
\text { 463, Ile 184,Ile } \\
\text { 250, Ile 457, Ile } \\
\text { 460, Leu 248, } \\
\text { Leu 337,Lys } \\
\text { 299,Phe 214, } \\
\text { Thr } 217 \text { and } \\
\text { Thr } 307\end{array}$ & $\begin{array}{c}\mathrm{N}-\mathrm{Ser} \\
251-\mathrm{Cl} 32\end{array}$ & HBA & 3.37 & $\begin{array}{l}\text { CB-Trp } \\
\text { 249- ring } \\
\text { CB-Phe } \\
\text { 461- ring } \\
\text { CD1-Phe } \\
\text { 461- ring }\end{array}$ & $\begin{array}{l}\pi-\mathrm{H} \\
\pi-\mathrm{H} \\
\pi-\mathrm{H}\end{array}$ & $\begin{array}{l}3.85 \\
4.20 \\
3.94\end{array}$ & 1.02 \\
\hline 4 & -6.92 & $\begin{array}{c}\text { Glu 462, Ile } \\
\text { 176, Ile 184,Ile } \\
\text { 250, Ile 457, Ile } \\
\text { 460, Leu 216, } \\
\text { Leu 248, Leu } \\
\text { 337,Lys } \\
\text { 299,Phe 214, } \\
\text { Ser 251, Thr } \\
\text { 217, Thr } 307 \\
\text { and Trp } 249\end{array}$ & - & - & - & $\begin{array}{l}\text { CB-Phe } \\
\text { 461- ring } \\
\text { CD1-Phe } \\
\text { 461- ring }\end{array}$ & $\pi-\mathrm{H}$ & 4.46 & 1.02 \\
\hline 6 & -5.74 & $\begin{array}{l}\text { Ala 180, Glu } \\
\text { 462, Gly 179, } \\
\text { Gly 222, Ile } \\
\text { 176, Ile } 184, \text { Ile } \\
\text { 250, Ile 460, } \\
\text { Leu 216, Leu } \\
\text { 248, Met } \\
\text { 344,Phe 214, } \\
\text { Ser 223, Ser } \\
\text { 251, Thr } 464 \\
\text { and Trp } 249\end{array}$ & $\begin{array}{c}\text { N-Thr } \\
217-\mathrm{Cl} 14\end{array}$ & HBA & 3.55 & $\begin{array}{l}\text { CB-Phe } \\
\text { 461- ring } \\
\text { N-Gly } \\
\text { 463- ring } \\
\text { CG2-Thr } \\
\text { 307-6- } \\
\text { ring }\end{array}$ & $\pi-\mathrm{H}$ & $\begin{array}{l}3.98 \\
4.12\end{array}$ & 0.45 \\
\hline 8 & -5.32 & $\begin{array}{c}\text { Glu 462, Ile } \\
\text { 176, Ile 184, Ile } \\
\text { 250, Ile 457, Ile } \\
\text { 460, Leu 248, } \\
\text { Leu 337,Phe } \\
\text { 214, Thr } 217 \\
\text { and Trp } 249\end{array}$ & $\begin{array}{c}\mathrm{N}-\mathrm{Ser} \\
251-\mathrm{Cl} 33\end{array}$ & HBA & 3.20 & $\begin{array}{l}\text { CB- Phe } \\
\text { 461- ring }\end{array}$ & $\pi-\mathrm{H}$ & 4.14 & 1.94 \\
\hline acetochlor & -6.26 & $\begin{array}{c}\text { Glu 462, Ile } \\
\text { 176, Ile 184, Ile } \\
\text { 250, Ile 457, } \\
\text { Leu 216, Leu } \\
\text { 337,Phe } 214, \\
\text { Phe } 461 \text {, Ser } \\
251 \text { and Trp } \\
249\end{array}$ & $\begin{array}{c}\text { N- Thr } \\
217-\mathrm{Cl} 38\end{array}$ & HBA & 3.36 & - & - & - & 1.90 \\
\hline
\end{tabular}

\footnotetext{
*The root means square deviation
} 


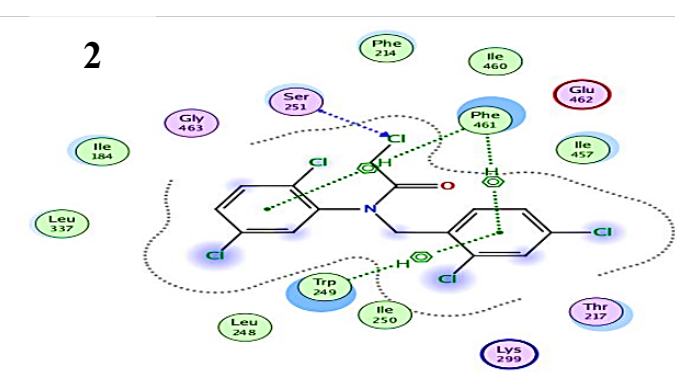

(ii하
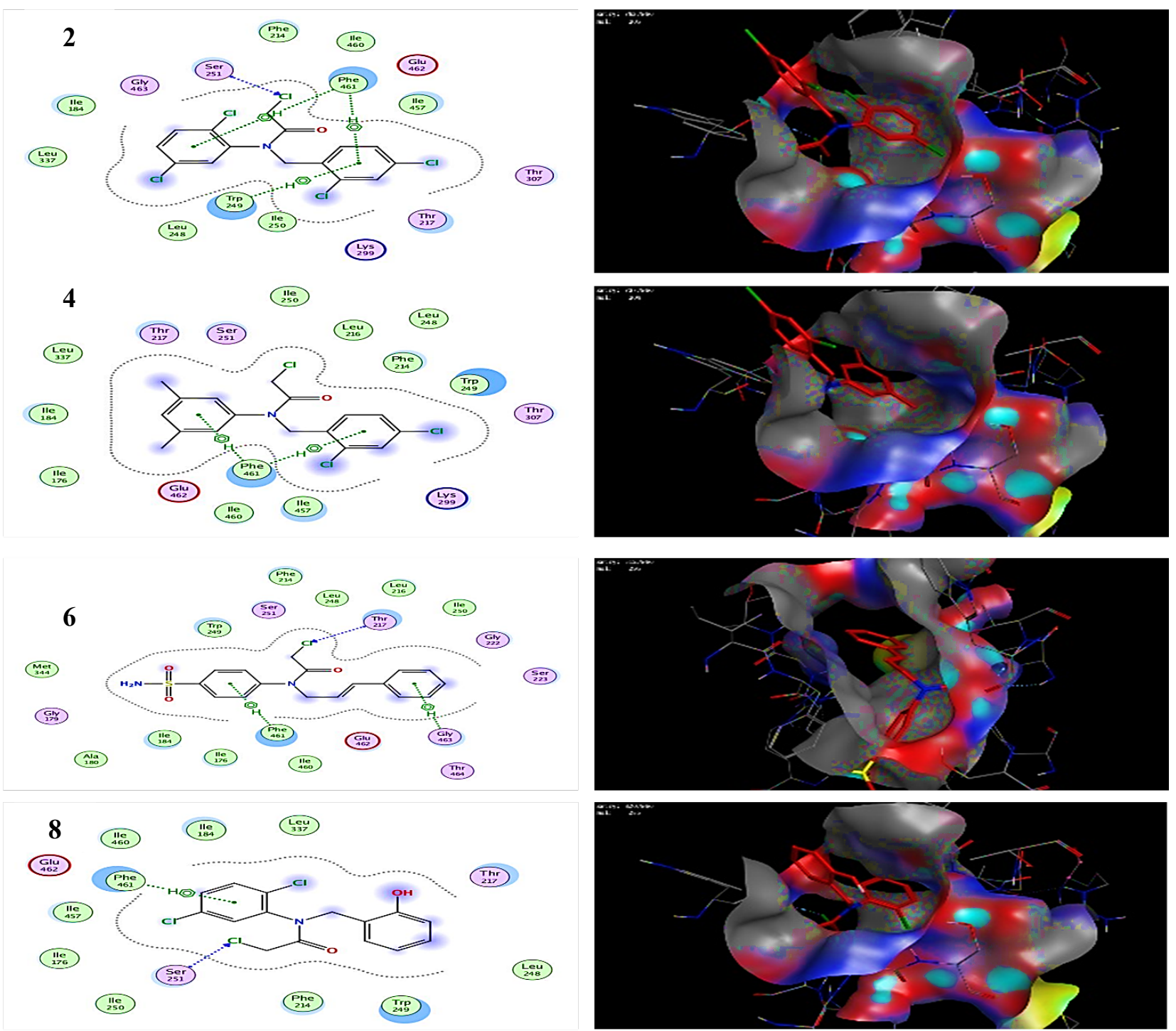

(누요
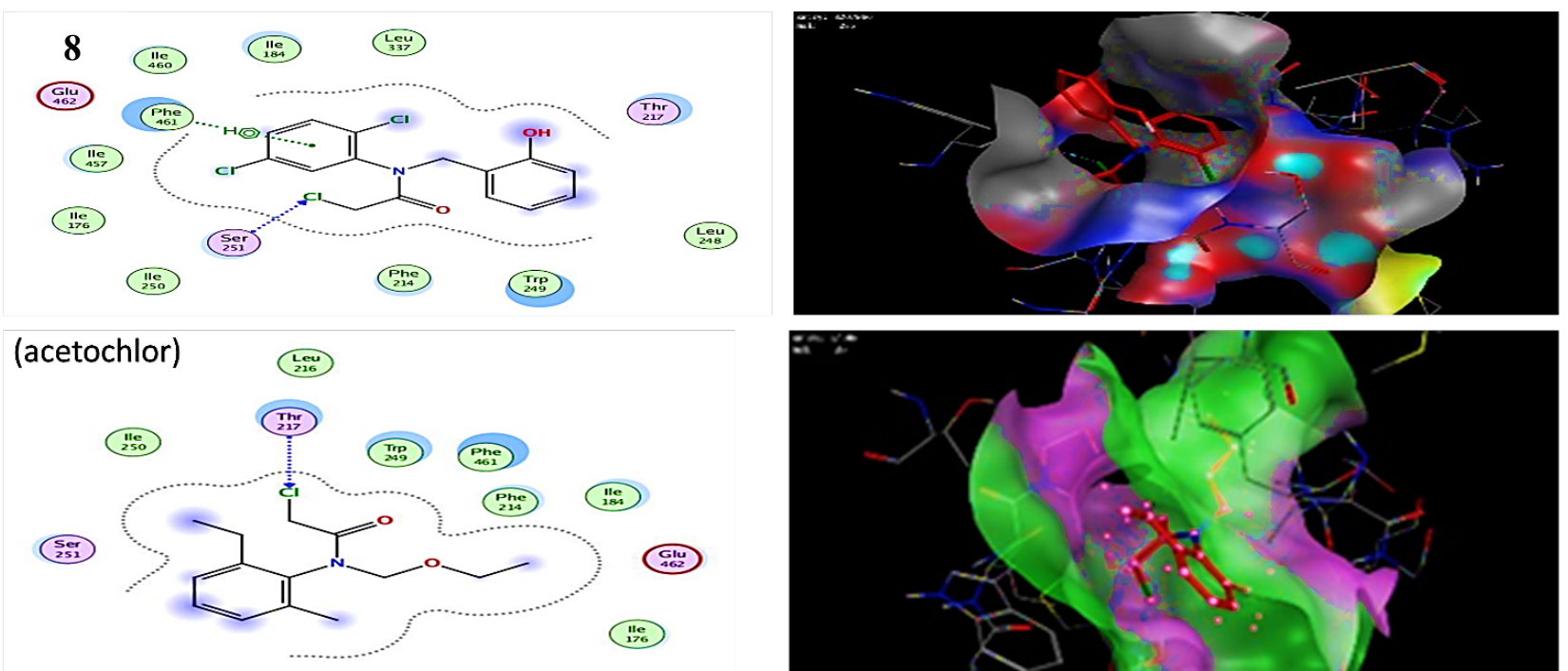

(15:9)

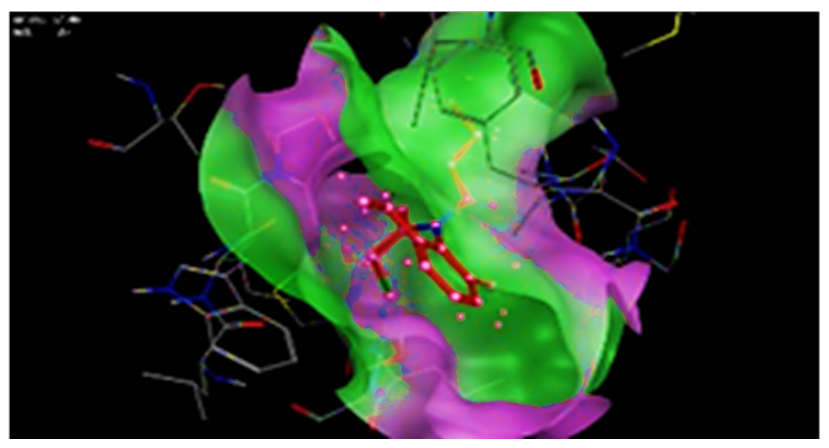

Figure 3. Docking of the synthesized compounds compared with the most popular standard herbicide acetochlor in the binding site of VLCFAs (PDB ID 2UXW). Left: 2D interaction diagram of compounds with 2UXW complex structures and right the 3D of the complex structure. 


\section{Conclusion}

Four novel chloroacetamide derivatives had been synthesized and evaluated for herbicidal activity. Spectral methods supported the chemical structures of the new compounds. The compounds were evaluated for in vitro herbicidal activity against two weeds, $A$. arvensis as broadleaf weed and $L$. temulentum as a grass weed were using the determination of chlorophyll content as an indicator of the effect. The herbicidal activity of the products containing the methyl group in the benzyl ring was determined to be the most potent. The in silico molecular docking of the synthesized compounds was supported the compounds' binding affinity to the active pocket of the target protein VLCFAs.

\section{REFERENCES}

Abdel-Latif, E., M.M. Fahad and M.A. Ismail. 2020.Synthesis of N-aryl 2-chloroacetamides and their chemical reactivity towards various types of nucleophiles Synthetic Communications 50:289-314

Böger, P. 2003. Mode of action for chloroacetamides and functionally related compounds Journal of Pesticide Science 28:324-329

Epp, J.B.2016.The discovery of Arylex ${ }^{\mathrm{TM}}$ active and Rinskor ${ }^{\mathrm{TM}}$ active: two novel auxin herbicides Bioorganic \& medicinal chemistry 24:362-371

Fu, Y., Y.N.Sun, K.H.Yi, M.Q.Li, H.F. Cao, J.Z.Li and F. Ye. 2017. 3D pharmacophore-based virtual screening and docking approaches toward the discovery of novel HPPD inhibitors Molecules 22:959

Fu, Y. 2019. Discovery of N-aroyl diketone/triketone derivatives as novel 4-hydroxyphenylpyruvate dioxygenase inhibiting-based herbicides Journal of agricultural and food chemistry 67:11839-11847

Gianessi, L.P. 2013.The increasing importance of herbicides in worldwide crop production Pest management science 69:1099-1105

Götz, T. and P. Böger. 2004.The very-long-chain fatty acid synthase is inhibited by chloroacetamides Zeitschrift für Naturforschung C 59:549-553

Halgren, T.A. 1999.MMFF VI. MMFF94s option for energy minimization studies Journal of Computational Chemistry 20:720-729

Heap, I. 2014. Global perspective of herbicide-resistant weeds Pest management science 70:1306-1315

Jeschke, P. 2016. Progress of modern agricultural chemistry and future prospects Pest management science 72:433455
Kraehmer, H., B. Laber, C. Rosinger and A.J.Pp. Schulz. 2014.Herbicides as weed control agents: state of the art: I. Weed control research and safener technology: the path to modern agriculture $166: 1119-1131$

Mallory-Smith, C.A. and E.J .Retzinger. 2003.Revised Classification of Herbicides by Site of Action for Weed Resistance Management Strategies1 Weed Technology 17:605-619

Matthes, B., J. Schmalfuß and P. Böger.1998. Chloroacetamide mode of action, II: Inhibition of very long chain fatty acid synthesis in higher plants Zeitschrift für Naturforschung C 53:1004-1011

Moche, M., K .Dehesh, P. Edwards and Y. Lindqvist. 2001. The crystal structure of $\beta$-ketoacyl-acyl carrier protein synthase II from Synechocystis sp. at $1.54 \AA$ resolution and its relationship to other condensing enzymes Journal of molecular biology 305:491-503

Murtaza, S., A.A.Altaf, M. Hamayun, K.Iftikhar, M.N.Tahir, J. Tariq and K. Faiz.2019. Synthesis, antibacterial activity and docking studies of chloroacetamide derivatives European Journal of Chemistry 10:358-366

Perotti, V.E., A.S.Larran, V.E.Palmieri, A.K.Martinatto and H.R. Permingeat. 2020. Herbicide resistant weeds: A call to integrate conventional agricultural practices, molecular biology knowledge and new technologies Plant Science 290:110255

Powles, S. 2014.Global herbicide resistance challenge Pest Manag Sci 70:1305

Saad, M.M., N.A.Gouda, S.A.Abdelgaleil, E.S.JJo and P.B. Health.2019. Bioherbicidal activity of terpenes and phenylpropenes against Echinochloa crus-galli 54:954963

Schmalfuß, J., B.Matthes, P. Mayer and P. Böger.1998. Chloroacetamide mode of action, I: Inhibition of very long chain fatty acid synthesis in Scenedesmus acutus Zeitschrift Fur Naturforschung C 53:995-1003

SPSS Inc., 2007

Vats, S. 2015. Herbicides: history, classification and genetic manipulation of plants for herbicide resistance. In: Sustainable agriculture reviews. Springer, pp: 153-192

Vekariya, M.B., J.S.Babariya, M.K.J.Jilariya. Synthesis and Characterization of some Novel Coumarin Derivative and Studyof Crystalography. Lulu. Com,

Xavier, A., N.Srividhya .2014. Synthesis and study of Schiff base ligands IOSR Journal of Applied Chemistry 7:06-15

Yamamoto, A., T. Nakamura, J .Adu-Gyamfi and M. Saigusa.2002.Relationship between chlorophyll content in leaves of sorghum and pigeonpea determined by extraction method and by chlorophyll meter (SPAD-502) Journal of Plant Nutrition 25:2295-2301 


\section{الملخص العربي \\ تخليق، النشاط الإبادي على الحشائش والإرساء الجزيئي لبعض مشتقات الكلوروأسيتاميد الجديدة \\ سعد رشاد الزميتي، كريم إسماعيل السيد و محمد الطاهر إبر اهيم بدوي}

الوزن الذري وكذلك تحليل الرنين النووي المغناطيسي ، NMR

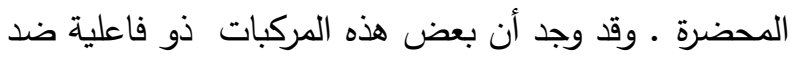

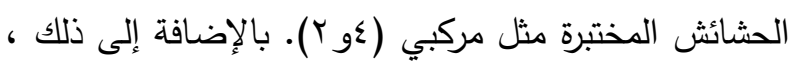
فإن نتائج الإرساء/الإلتحام الجزئي للمركبات المحضرة مع المواقع النشطة للإنزيم المسئول عن تخليق الأحماض الإن الدهنية طويلة السلسلة جدًا (VLCFAs) في النبات باعتباره إنزيمًا مستهدفًا أظهرت أن المشتقات أعطت الحد الأدنى من طاقة الارتباط والتقارب المقبول للموقع النشط.
تم تخليق أربعة من مشتقات الكلورو أسيتاميد الجديدة -Chloro- $N-(2,4-$ dichlorobenzyl)-N-(3,5- وهي dimethylphenyl)acetamide (2), 2-Chloro- $\mathrm{N}-(2,4-$ dichlorobenzyl)-N-(2,5-dichlorophenyl)acetamide (4), 2-Chloro-N-cinnamyl-N-(4-sulfamoylphenyl)acetamide (6) and 2-Chloro- $\mathrm{N}-(2,5-$ dichlorophenyl) $-\mathrm{N}-(2-$ وتقييم النشاط الإبادي لها ضد نوعين من الحشائش حشيشة الزغلنت (عين القط أو صابون العرب) Anagallis arvensis كمثال للحشائش عريضة الأوراق وحشيشة الصامة Lolium temulentum كمثال للحشائش رفيعة الأوراق بالمقارنة مع الأسيتوكلور كمبيد حشائش قياسي. أكدت تحليل مطياف الكتلة لإيجاد 